\title{
厚肉球の弾・塑・粘塑性球面波伝ぱの解析*
}

\section{An Analysis of Propagation of Elastic-Plastic-Viscoplastic Spherical Waves in a Thick-Walled Sphere}

\author{
Noboru TANIMOTO *1 \\ ${ }^{* 1}$ 4-3-18 Kameura, Ube-shi, Yamaguchi-ken, 755-0002 Japan
}

\begin{abstract}
An analysis of dynamic behavior is carried out in the case when dynamic load with central symmetry is applied on the inner face of the cavity with central symmetry of the thick-walled elastic-plastic-viscoplastic sphere. Formulas are derived of propagation speeds of elastic-plastic-viscoplastic spherical waves. The theoretical formula is analytically proved to be strain rate and stress rate dependent. Ordinary differential equations among physical quantities are derived along characteristic curves. The propagation theory of spherical wave based on the elastic-plastic-viscoplastic constitutive equation is shown to contain that based on the elastic-plastic constitutive equation. Calculated examples are shown on the basis of the elastic-plastic-viscoplastic theory. A comparison is done of calculated results based on the elastic-plastic-viscoplastic theory with those based on the elastic-plastic theory.
\end{abstract}

Key Words : Spherical Wave, Stress Wave, Propagation Speed, Inelasticity, Strain Rate, Stress Rate, Under Stress, Over Stress, Plasticity, Viscoplasticity, Wave Propagation.

\section{1. 緒言}

固体材料の非弾性球面波伝ぱに関する研究は多くなされている(1)-(6) .しかし, 大部分がずみ速度不依存性材 料についての研究である.例えば文献 (6) では,ひずみ速度不依存性である塑性ポテンシャル型弾・塑性構成式 を用いた弾・塑性球面波伝ぱの解析か行われている．ところが, 実在の固体材料は, 多かれ少なかれ，ひずみ速 度依存性を示す．ひずみ速度依存性材料に関する研究では, 弾・粘塑性体に動的グリーン関数を用いた球面波の 伝ぱの理論解析と計算がなされている ${ }^{(5)}$. しかし，周知のように，弾・粘塑性構成式を用いた一次元棒の理論応 力波伝ぱ速度は弾性波の伝ぱ速度と同じとなり，弾・粘塑性波動伝ば理論は不十分であろう

本論文では,ひずみ速度依存性弾・塑・粘塑性厚肉球内の球面波伝ぱの理論解析を, 特性曲線法を用いて行う. 乥こでは, 球面弾・塑・粘塑性波の伝ば速度の式, 特性曲線に沿った粒子速度, 応力およびひずみなどの関係式 を示す. 乥して, 光の計算例も示す.このとき, 既存の，ひずみ速度不依存性である, 塑性ひずみが塑性ポテン シャルで表現された（以後，塑性ポテンシャル型と呼ぶ）弾・塑性構成式を用いた場合の計算結果 ${ }^{\left({ }^{(}\right)}$との比較も 行う . また , 球面弾・塑・粘塑性波伝ぱ速度の理論式かひずみ速度および忍力速度依存性であることを解析的に 示す.さらに, 弾・塑・粘塑性球面波伝ぱ理論が, 塑性ひずみが過小応力で表現された（以後, 過小応力型と呼 ぶ）弾・塑性球面波伝ば理論を含むことを示し，光して，この過小応力型弾・塑性球面波伝ば理論が, 塑性ポテ ンシャル型弾・塑性球面波伝ば理論と同一になることを示す．なお，変形は微小変形であり，等温変形を扱う.

\section{2. 基 礎 式}

曲線座標系における運動方程式および連続の式は次式で与えられる(8).

\footnotetext{
* 原稿受付 2010 年 3 月 25 日

*1 正員，( T 755-0002 山口県宇部市亀浦 4-3-18)

E-mail: n-tani2103@ac.auone-net.jp
} 


$$
\begin{gathered}
\dot{\rho v^{i}}=\left.\tau^{i j}\right|_{j} \\
\dot{\gamma}_{i j}=\left(\left.v_{i}\right|_{j}+\left.v_{j}\right|_{i}\right) / 2
\end{gathered}
$$

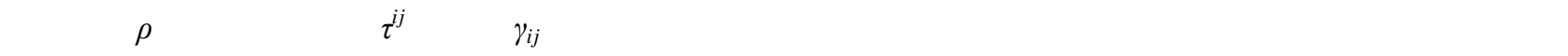
あり, $v^{i}$ および $v_{i}$ は, 弚れ光れ, 粒子速度べクトルの反変および共変成分である $\left.\right|_{j}$ (右下添字 $j$ 付き縦線)

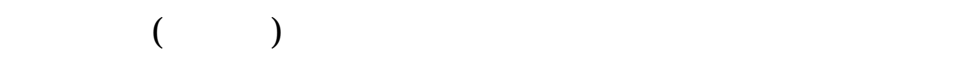

非圧縮性弾・塑・粘塑性構成式は直角座標系で次式で与えられる ${ }^{(7)}$.

$$
\dot{\varepsilon}_{i j}= \begin{cases}\left\{\frac{1}{2 \mu}+\Psi(H)\right\} \dot{\sigma}_{i j}+\Phi(F) \sigma_{i j}-\frac{1}{3} \delta_{i j}\left[\left\{\frac{3 v}{2 \mu(1+v)}+\Psi(H)\right\} \dot{\sigma}_{k k}+\Phi(F) \sigma_{m m}\right] & \text { when } F>0 \\ \frac{1}{2 \mu}\left(\dot{\sigma}_{i j}-\frac{v}{1+v} \delta_{i j} \dot{\sigma}_{n n}\right) & \text { when } F \leq 0\end{cases}
$$

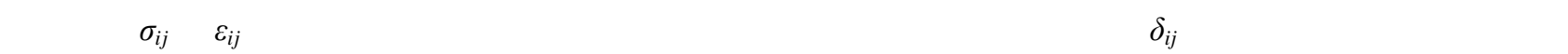

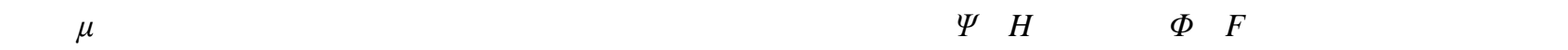
化過小応力関数 (あるいは, 一般化塑性関数) と一般化過大応力関数 (あるいは, 一般化粘塑性関数) であ る. 光して,

$$
\begin{aligned}
& \Psi(H)=H^{k_{1}} / \zeta, \Phi(F)=F^{k_{2}} / \eta \\
& H=\sqrt{J_{2}{ }^{E}} / \sqrt{J_{2}}-1, \quad F=R_{S}{ }^{\overline{J_{3}}} \sqrt{J_{2}} /\left|\tau_{S}\right|-1=R_{S}^{\overline{J_{3}}-1} \sqrt{3 J_{2}} /\left|\sigma_{S}\right|-1 \\
& \overline{J_{3}}=(3 \sqrt{3} / 2) J_{3} / J_{2}{ }^{3 / 2}, J_{2}=s_{i j} s_{j i} / 2, J_{3}=s_{i j} s_{j k} s_{k i} / 3 \\
& R_{S}=\sqrt{3}\left|\tau_{S} / \sigma_{S}\right|, \quad \tau_{S}=\tau_{S}(\sqrt{3} L), \quad \sigma_{S}=\sigma_{S}(L), L=\int \sqrt{2 d e_{i j} d e_{j i} / 3} \\
& \sqrt{J_{2}{ }^{E}}=2 \mu \sqrt{I_{2}{ }^{E}} \\
& I_{2}{ }^{E}=\left(I_{2}^{e}\right)_{O_{1}, O_{2}, O_{3}} \\
& \mathrm{O}_{2}:=\{\text { コーシーの法則を用いて運動方向の弾性ひずみ成分だけにする }\}
\end{aligned}
$$

$$
I_{2}{ }^{e}=e_{k m}^{e} e_{m k}^{e} / 2, e^{e}{ }_{i j}=\varepsilon^{e}{ }_{i j}-\delta_{i j} \varepsilon_{k k}^{e} / 3
$$

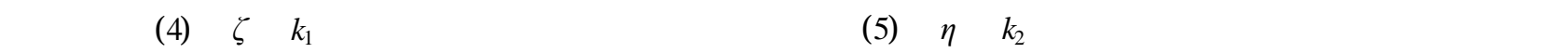
式 6)，Hと(7a，b)，Fは，光れ光れ，一般化無次元過小応力と一般化無次元過大応力である.式 (8)， $\overline{J_{3}}$ は無次元偏差応 カテンソルの第 3 不変量であり, 光して, 式 $(9), J_{2}$ と式 (10)， $J_{3}$ は, 乥れ光れ，偏差心力テンソルの第 2 および 3 不変量 である . $s_{i j}$ は偏差応力テンソルの成分である . 式 11$), R_{S}$ は, 静的横縦応力比 , すなわち, 静的単純せん断応力 $\tau_{S}$ と引張 


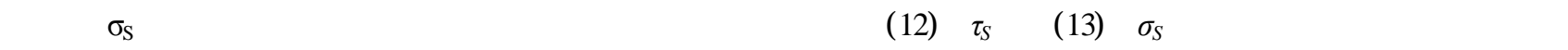
およびと引張り応力の次の実験式，

$$
\tau_{S}=\tau_{S}\left(\gamma_{S}\right), \sigma_{S}=\sigma_{S}\left(\varepsilon_{S}\right)
$$

において, 現在 (変形中) の弧ひずみ (相当ひずみ) $L$ を用いて, $\gamma_{S}=3^{1 / 2} L$ と $\varepsilon_{S}=L$ と置換した , 式 (12) と (13) を用いなければならない.式( 14)，Lの右辺の $e_{i j}$ は偏差ひずみテンソルの成分である . 式 $(15),\left(J_{2}^{E}\right)^{1 / 2}$ は一般 化上限応力 (以前, 仮応力と呼んでいた) であり, 一般化応力・一般化ひずみ平面上, $\left(J_{2}\right)^{1 / 2}-\left(I_{2}^{E}\right)^{1 / 2}$ 平面上での， 一般化上限点 (現在の応力とひずみを通る, 絴応力軸に平行な直線と, 弾性直線の延長線との交点) の応力であ る . $J_{2}{ }^{E}$ は偏差上限応力テンソルの第 2 不変量 $J_{2}{ }^{E}=s_{i j}{ }_{i j} S_{i j} / 2$ でもある.$s^{E}{ }_{i j}$ は偏差上限応力テンソルの成分である . 式(15)の右辺の $\left(I_{2}{ }^{E}\right)^{1 / 2}$ は, 一般化ひずみであり，式(16)〜 (19) から求めることができる . 式( 18)， $I_{2}{ }^{e}$ は偏差弾 性ひずみテンソルの第 2 不変量であり, 式(19)， $e_{i j}^{e}$ は偏差弾性ひずみテンソルの成分である . 式( 16)の右辺は, ( ) 内の関数 $I_{2}{ }^{e}$ に操作 $\mathrm{O}_{1}, \mathrm{O}_{2}$ および $\mathrm{O}_{3}$ を，この順序で行うことを表す . 操作 $\mathrm{O}_{1}$ を行うとき，これと同時に， 式 (15) の左辺の関数 $J_{2}{ }^{E}$ の引数である上限応力の成分 $\sigma^{E}{ }_{k m}$ の中で零となる成分を消去することも必要である.式 (15)は,コーシーの法則を用いて導出された不変量間の関係式，

$$
\sqrt{J_{2}}=2 \mu \sqrt{I_{2}{ }^{e}}
$$

から求めることかできる゙ .

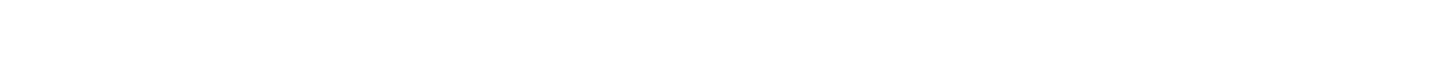

$$
\dot{L}=\sqrt{2 / 3} \dot{e}_{i j} e_{i j} / \sqrt{e_{k m} e_{k m}}, \bar{\sigma}=\sqrt{3 J_{2}}, \dot{\bar{\sigma}}=\sqrt{3 / 2} \dot{s}_{i j} s_{i j} / \sqrt{s_{k m} s_{k m}}
$$

相当応力, 弧ひずみおよび弧ひずみ速度を用いると，相当応力・弧ひずみ平面上で弧ひずみ速度をパラメー タとして , 多軸応力状態を単一の平面上で議論することが可能となる .

\section{3. 厚肉球の解析}

\section{$3 \cdot 1$ 基礎式}

半径 $r_{i}$ の球状空洞を中心対称に有する外半径 $r_{o}$ の厚肉球において, 空洞に点対称の動的荷重 $v_{i}(t)$ を負荷する場 合を考えるので, 変形状態は中心 $\mathrm{O}$ に関して点対称である (図 1).

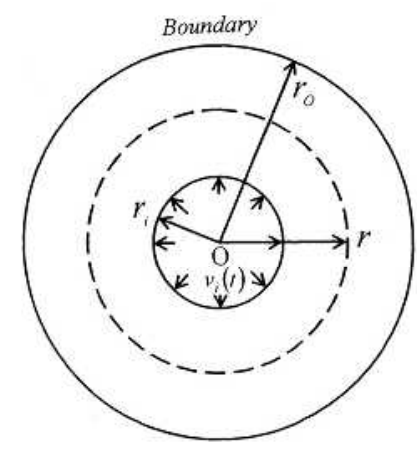

Fig.1 Thick-walled sphere.

Particle velocity loading condition.

ラグランジュ座標を採用し，球座標 $(r, \varphi, \theta)$ を採用する. $\varphi$ 方向の物理量と $\theta$ 方向の关れは同じである.物理 量は時間 $t$ と半径方向位置 $r$ の関数である. 半径方向の運動方程式は, 式(1) から物理成分 ${ }^{(8),(9)}$ を用いて, 次式と なる 


$$
\rho \frac{\partial v_{r}}{\partial t}=\frac{\partial \sigma_{r r}}{\partial r}+\frac{2}{r}\left(\sigma_{r r}-\sigma_{\varphi \varphi}\right)
$$

ここで， $v_{r}$ は半径方向粒子速度であり， $\sigma_{r r}$ と $\sigma_{\varphi \varphi}\left(=\sigma_{\theta \theta}\right)$ は，乥れ光れ，半径方向および周方向応力である． 半径方向と周方向の連続の式は, 弚れ光れ, 式(2)から物理成分を用いて, 次式となる .

$$
\frac{\partial \varepsilon_{r r}}{\partial t}=\frac{\partial v_{r}}{\partial r}, \frac{\partial \varepsilon_{\varphi \varphi}}{\partial t}=\frac{v_{r}}{r}
$$

ここで, $\varepsilon_{r}$ と $\varepsilon_{\varphi \rho}\left(=\varepsilon_{\theta \theta}\right)$ は, 弚れ光れ , 半径方向および周方向ひずみである.非弾生変形は非圧縮生であると仮定しているの

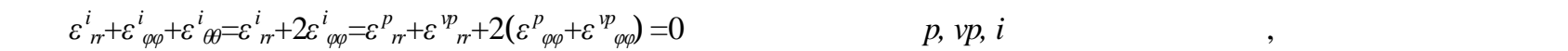
ずみを表す . 半径方向と周方向の弾・塑・粘塑性構成式は, 弚れ光れ, 式(3)から , 次式となる.

$\frac{\partial \varepsilon_{r r}}{\partial t}=\left\{\begin{array}{ll}\frac{1}{E} \frac{\partial \sigma_{r r}}{\partial t}-\frac{2 v}{E} \frac{\partial \sigma_{\varphi \varphi}}{\partial t} & \text { when } F \leq 0 \\ p \frac{\partial \sigma_{r r}}{\partial t}-2 s \frac{\partial \sigma_{\varphi \varphi}}{\partial t}+2 f \Phi & \text { when } F>0\end{array}, \frac{\partial \varepsilon_{\varphi \varphi}}{\partial t}= \begin{cases}-\frac{v}{E} \frac{\partial \sigma_{r r}}{\partial t}+\frac{1-v}{E} \frac{\partial \sigma_{\varphi \varphi}}{\partial t} & \text { when } F \leq 0 \\ -s \frac{\partial \sigma_{r r}}{\partial t}+q \frac{\partial \sigma_{\varphi \varphi}}{\partial t}-f \Phi & \text { when } F>0\end{cases}\right.$ ここで，

$$
p=1 / E+2 \Psi / 3, q=(1-v) / E+\Psi / 3, s=v / E+\Psi / 3, f=\left(\sigma_{r r}-\sigma_{\varphi \varphi}\right) / 3 \quad \text { (31), (32), (33), (34) }
$$

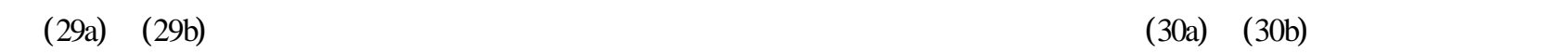
向の光れらを表現する.式(27)と(29a, b)，および,式(28)と(30a,b)から，光れ光れ，次式を得る.

$$
\frac{\partial v_{r}}{\partial r}=\left\{\begin{array}{l}
\frac{1}{E} \frac{\partial \sigma_{r r}}{\partial t}-\frac{2 v}{E} \frac{\partial \sigma_{\varphi \varphi}}{\partial t} \quad \text { when } F \leq 0 \\
p \frac{\partial \sigma_{r r}}{\partial t}-2 s \frac{\partial \sigma_{\varphi \varphi}}{\partial t}+2 f \Phi \text { when } F>0
\end{array}, \frac{v_{r}}{r}=\left\{\begin{array}{l}
-\frac{v}{E} \frac{\partial \sigma_{r r}}{\partial t}+\frac{1-v}{E} \frac{\partial \sigma_{\varphi \varphi}}{\partial t} \quad \text { when } F \leq 0 \\
-s \frac{\partial \sigma_{r r}}{\partial t}+q \frac{\partial \sigma_{\varphi \varphi}}{\partial t}-f \Phi
\end{array} \quad \text { when } F>0 \quad(35 \mathrm{a}, \mathrm{b}),(36 \mathrm{a}, \mathrm{b})\right.\right.
$$

$H$ は式(6)，(9)および(15)〜 (19) から，光して，F は式( 7a, b)〜 (14) から , 次式となる .

$$
H=\frac{2 \mu\left|\varepsilon_{r r}-\varepsilon_{\varphi \varphi}\right|}{\left|\sigma_{r r}-\sigma_{\varphi \varphi}\right|}-1, \quad F=\frac{R_{S}^{\overline{J_{3}}}\left|\sigma_{r r}-\sigma_{\varphi \varphi}\right|}{\sqrt{3}\left|\tau_{S}\right|}-1=\frac{R_{S}^{\overline{J_{3}}-1}\left|\sigma_{r r}-\sigma_{\varphi \varphi}\right|}{\left|\sigma_{S}\right|}-1
$$

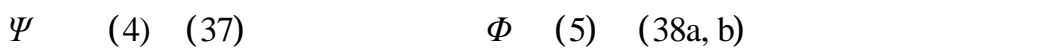

$$
\Psi=\frac{1}{\zeta}\left(\frac{2 \mu\left|\varepsilon_{r r}-\varepsilon_{\varphi \varphi}\right|}{\left|\sigma_{r r}-\sigma_{\varphi \varphi}\right|}-1\right)^{k_{1}}, \Phi=\frac{1}{\eta}\left(\frac{R_{S}^{\bar{J}_{3}}\left|\sigma_{r r}-\sigma_{\varphi \varphi}\right|}{\sqrt{3}\left|\tau_{S}\right|}-1\right)^{k_{2}}=\frac{1}{\eta}\left(\frac{R_{S}^{\overline{J_{3}}}-1\left|\sigma_{r r}-\sigma_{\varphi \varphi}\right|}{\left|\sigma_{S}\right|}-1\right)^{k_{2}} \quad \text { (39), (40a, b) }
$$

$J_{2}, J_{3}$ おび $J_{3}$ は, 弚れ光れ, 式( 9), (10)および 8)から , 次式となる . 


$$
J_{2}=\left(\sigma_{r r}-\sigma_{\varphi \varphi}\right)^{2} / 3, \quad J_{3}=(2 / 27)\left(\sigma_{r r}-\sigma_{\varphi \varphi}\right)^{3}, \quad \overline{J_{3}}=\left\{\begin{array}{ll}
1 & \text { when }\left(\sigma_{r r}-\sigma_{\varphi \varphi}\right) \geq 0 \\
-1 & \text { when }\left(\sigma_{r r}-\sigma_{\varphi \varphi}\right)<0
\end{array} \quad(41),(42),(43 \mathrm{a}, \mathrm{b})\right.
$$

式(12)と(20)の $\tau_{S}$ と，式(13)と(21)の $\sigma_{S}$ は，光れぞれ，次式の形式を採用する .

$$
\sqrt{3} L=\frac{\tau_{S}}{\mu}+a_{1}\left(\left|\frac{\tau_{S}}{\tau_{Y}}\right|-1\right)^{b_{1}}, L=\frac{\sigma_{S}}{E}+a\left(\left|\frac{\sigma_{S}}{\sigma_{Y}}\right|-1\right)^{b}
$$

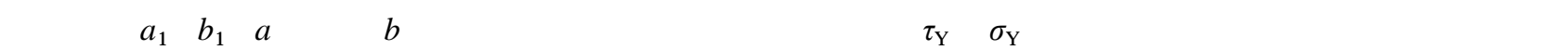
り試験の初期降伏応力である . 一次元棒の静的単純引張り応力・ひずみ曲線は滑らかであり，ひずみ軸に対 して凹型であると仮定している．静的単純せん断曲線も静的単純引張り曲線と同樣である . 弧ひずみ，弧ひ ずみ速度，相当応力および相当応力速度は，光れ光れ，式(14)，(23)，(24)および(25)から，次式となる．

$$
\begin{gathered}
L=(2 / 3)\left|\varepsilon_{r r}-\varepsilon_{\varphi \varphi}\right|, \quad \dot{L}=\frac{2}{3}\left(\dot{\varepsilon}_{r r}-\dot{\varepsilon}_{\varphi \varphi}\right)\left(\varepsilon_{r r}-\varepsilon_{\varphi \varphi}\right) /\left|\varepsilon_{r r}-\varepsilon_{\varphi \varphi}\right| \\
\bar{\sigma}=\left|\sigma_{r r}-\sigma_{\varphi \varphi}\right|, \quad \dot{\bar{\sigma}}=\left(\dot{\sigma}_{r r}-\dot{\sigma}_{\varphi \varphi}\right)\left(\sigma_{r r}-\sigma_{\varphi \varphi}\right) /\left|\sigma_{r r}-\sigma_{\varphi \varphi}\right|
\end{gathered}
$$

式(46)，(47)および (49) は更に変形が可能である ${ }^{(6)}$. 任意の半径方向位置 $r$ での半径方向変位 $w_{r}$ は次式から求 めることができる .

$$
v_{r}=\frac{\partial w_{r}}{\partial t}
$$

ここで, 過小応力 $H$ について, 式(6)から式(37)の導出過程を示す．まず式(18) を成分表示する.

$$
I_{2}^{e}=\left(\varepsilon^{e}{ }_{11}^{2}+\varepsilon^{e}{ }_{22}^{2}+\varepsilon^{e}{ }_{33}^{2}-\varepsilon_{11}^{e} \varepsilon_{22}^{e}-\varepsilon^{e}{ }_{22} \varepsilon_{33}^{e}-\varepsilon^{e}{ }_{33} \varepsilon_{11}^{e}\right) / 3+\varepsilon_{12}^{e}+\varepsilon_{23}^{e}+\varepsilon_{31}^{e}
$$

第2 番目に , 式( 16)，(17a)および( 51) から次式を得る.

$$
\left(I_{2}^{e}\right)_{O_{1}}=\left(\varepsilon^{e}{ }_{11}^{2}+\varepsilon^{e}{ }_{22}^{2}+\varepsilon^{e}{ }_{33}^{2}-\varepsilon^{e}{ }_{11} \varepsilon_{22}^{e}-\varepsilon^{e}{ }_{22} \varepsilon_{33}^{e}-\varepsilon^{e}{ }_{33} \varepsilon_{11}^{e}\right) / 3
$$

第 3 番目に，式( 16)，(17b) および( 52) から次式を得る .

$$
\left(I_{2}^{e}\right)_{O_{1}, O_{2}}=\left(\varepsilon^{e}{ }_{11}-\varepsilon^{e} 22\right)^{2} / 3
$$

ここで, $\varepsilon_{22}^{e}=\varepsilon_{33}^{e}$ を用いた．第 4 番目に，式(16), (17c)および (53)から次式を得る.

$$
\left(I_{2}{ }^{e}\right)_{O_{1}, O_{2}, O_{3}}=\left(\varepsilon_{11}-\varepsilon_{22}\right)^{2} / 3
$$

最後に，式(6)，(15)，(16)，(41)および( 54)から，式(37)を得る .ここで， $\varepsilon_{11}=\varepsilon_{r r}$ と $\varepsilon_{22}=\varepsilon_{\varphi \varphi}$ である .

\section{$3 \cdot 2$ 特性曲線法による解析}

式(26)，(35b) および(36b) を行列表示すると次式を得る .

$$
\boldsymbol{L}(\boldsymbol{W})=\boldsymbol{A} \boldsymbol{W}_{t}+\boldsymbol{B} \boldsymbol{W}_{r}-\frac{1}{r} \boldsymbol{D W}=0
$$


ここで，

$$
\boldsymbol{A}=\left[\begin{array}{ccc}
\rho & 0 & 0 \\
0 & p & -2 s \\
0 & -s & q
\end{array}\right], \boldsymbol{B}=\left[\begin{array}{ccc}
0 & -1 & 0 \\
-1 & 0 & 0 \\
0 & 0 & 0
\end{array}\right], \boldsymbol{D}=\left[\begin{array}{ccc}
0 & 2 & -2 \\
0 & -2 g & 2 g \\
1 & g & -g
\end{array}\right], \boldsymbol{W}=\left[\begin{array}{c}
v_{r} \\
\sigma_{r r} \\
\sigma_{\varphi \varphi}
\end{array}\right] \quad \text { (56a) , (56b), (56c), (56d) }
$$

である.灷て，

$$
g=(\Phi / 3) r
$$

式( 55$)$ は, $v_{r}, \sigma_{r r}$ および $\sigma_{\varphi \varphi}$ を末知関数とする，1階・偏微分方程式であり，特性曲線法て解くことができる . 式 (55) は $F \leqq 0$ のき弾性挙動を表すが, この場合, $\Psi=0$ および $\Phi=0$ と置けば良い . 伝ぱ速度 $d r / d t=\lambda_{(k)}$ を求める式 は，特性方程式 $\left|\lambda_{(k)} A-B\right|=0$ から，次式となる .

$$
\lambda_{(k)}\left\{\rho \lambda_{(k)}^{2}(p-2 s)(p+s)-q\right\}=0
$$

式( 58) から $\lambda_{(1)}=c, \lambda_{(2)}=-c$ および $\lambda_{(3)}=0$ となる . ここで ,

$$
c=\sqrt{\frac{\frac{1-v}{E}+\frac{\Psi}{3}}{\rho \frac{1-2 v}{E}\left(\frac{1+v}{E}+\Psi\right)}}
$$

である.式( 59)， $c$ か理論弾・塑・粘塑性球面波伝ぱ速度である.式( 59) は過小応力関数 $\Psi$ を陽に含み, 過大応 力関数 $\Phi$ を陽に含まない． $\Phi$ を陽に含む球面弾・塑・粘塑性波伝ぱ速度 $c$ は第 3.3 節で与えられる. 弾性変形の とき，すなわち， $F \leqq 0$ のき $\Psi=0$ および $\Phi=0$ であるので, 式( 59) は球面弾性波伝ぱ速度 (すなわち，平面弾性 波伝ぱ速度) $c_{1}$ の式となる

$$
c_{1}=\sqrt{\frac{E(1-v)}{\rho(1-2 v)(1+v)}}=\sqrt{\frac{\lambda+2 \mu}{\rho}}
$$

$\lambda$ はラーメの定数である .この $\lambda$ は式( 56) の $\lambda_{(k)}$ と異なる.$c$ と $c_{1}$ の大小関係は次式となる.

$$
c \leq c_{1}
$$

次に，特性曲線に沿った各物理量の微分関係式を求める . 固有值 $\lambda_{(k)}$ に対応して固有ベクトル $\boldsymbol{l}_{(k)}$ が存在して, $\boldsymbol{l}_{(k)}{ }^{\mathrm{T}} \cdot\left(\lambda_{(k)} \boldsymbol{A}-\boldsymbol{B}\right)=0$ から次式を得る .

$$
I_{(1)}=\left\{\begin{array}{c}
1 \\
-\rho c \\
-\rho c z
\end{array}\right\}, I_{(2)}=\left\{\begin{array}{c}
1 \\
\rho c \\
\rho c z
\end{array}\right\}, I_{(3)}=\left\{\begin{array}{l}
0 \\
0 \\
1
\end{array}\right\}
$$

ここで，

$$
z=2 s / q
$$

である . 線形結合 $\boldsymbol{l}^{\mathrm{T}} \cdot \boldsymbol{L}=0$ から，特性曲線 $d r / d t=\lambda_{(k)}$ に沿った常微分方程式を得る . 


$$
\begin{gathered}
\frac{d \sigma_{r r}}{d t} \mp \rho c \frac{d v_{r}}{d t} \pm \frac{c}{r}\left(6 f \mp \rho c v_{r} z\right)+\rho c^{2} f \Phi(2-z)=0 \quad \text { along } \frac{d r}{d t}= \pm c \\
s \frac{d \sigma_{r r}}{d t}-q \frac{d \sigma_{\varphi \varphi}}{d t}+\frac{v_{r}}{r}+f \Phi=0 \quad \text { along } \frac{d r}{d t}=0
\end{gathered}
$$

厚肉球に生じる物理量は, $r-t$ 平面上で格子を作り，特性曲線に沿って式 $(64 \mathrm{a}, \mathrm{b}, \mathrm{c})$ を数値積分することによっ て求めることができる .

\section{$3 \cdot 3$ 弾・塑・粘塑性球面波伝ば速度 $\mathrm{c}$ の別形式}

第 $3 \cdot 3$ 節では，球面波伝ぱ速度の別形式を導出する．光れらは次式である．

$$
c=c_{3} \sqrt{1+\frac{4 \mu}{3 K(1+2 \mu \Psi)}}, \quad c=c_{1} \sqrt{\frac{3(1-v)+2 \mu(1+v) \Psi}{3(1-v)(1+2 \mu \Psi)}}
$$

$$
c=c_{3} \sqrt{1+\frac{2\left(\dot{\sigma}_{r r}-\dot{\sigma}_{\varphi \varphi}\right)}{3 K\left\{\dot{\varepsilon}_{r r}-\dot{\varepsilon}_{\varphi \varphi}-\left(\sigma_{r r}-\sigma_{\varphi \varphi}\right) \Phi\right\}}}, c=c_{3} \sqrt{1+\frac{ \pm 4 \bar{\sigma}}{3 K(3 \dot{L} \mp 2 \Phi \bar{\sigma})}}
$$

ここで， $c_{3}$ は体積弾性波伝ぱ速度であり，Kは体積弾性係数である

$$
c_{3}=\sqrt{\frac{K}{\rho}}=\sqrt{\frac{E}{3 \rho(1-2 v)}}
$$

式( 65a) と (65b) は, 式( 59) に弾性係数間の関係式を考慮すると求めることができる . 式( 65c) と式( 65d) は以下の ようにして求めることができる．ラグランジュ座標を採用しているので，

$$
\frac{\partial}{\partial t}=\frac{d}{d t} \text { in Lagrange coordinates }
$$

である. 呂て, 位置・時間平面上の特性曲線に沿って成立する関数の引数, 位置と時間は, 兴れ光れ, 位置・ 時間平面上の関数の引数, 位置と時間に含まれるので, 次式が成立する .

$$
\{r \text { and } t \mid \text { along } d r / d t= \pm c, 0 \text { in } r-t \text { plane }\} \subseteq\{r \text { and } t \mid \text { in } r-t \text { plane }\}
$$

式(67)と(68)を考慮すると，式( 29b)と(30b)から，次式が成立する .

$$
\dot{\varepsilon}_{r r}-\dot{\varepsilon}_{\varphi \varphi}=\left(\frac{1}{2 \mu}+\Psi\right)\left(\dot{\sigma}_{r r}-\dot{\sigma}_{\varphi \varphi}\right)+\left(\sigma_{r r}-\sigma_{\varphi \varphi}\right) \Phi \quad \text { when } F>0
$$

従って, 式( 65c) は式( 65a) に式( 69) を代入すると求めることができる . 式( 65d) は式( 65c) に式( 47)，(48)および (49) を考慮すると求めることができる.弾・塑・粘塑性球面波伝ぱ速度 $c$ は, 式( 59) および式( 65a)〜 ( 65d) から , 応力およびひずみ依存性の他に, 応力速度およひひずみ速度依存性であることが判る． 


\section{$3 \cdot 4$ 過小応力型弾・塑生球面波伝は速度の式 $c_{e-p / \Psi}$}

第 3.4 節では,ひずみ速度依存性弾・塑・粘塑性球面波伝ぱ速度 $c$ から，ひずみ速度不依存性弾・塑性球面波 伝ば速度 $c_{e-p}$ を導出することができることを示す . 記号 $c_{e-p}$ の右下添字 $e-p$ は , 弾・塑性体を表す . 式 $(40 \mathrm{a}, \mathrm{b})$ で 粘塑性係数, $\eta=\infty$, 従って, 過大応力関数, $\Phi=0$ のとき, 式(59)の $c$ は弾・塑性球面波伝ぱ速度 $c_{e-p}=c_{e-p / \Psi}$ とな る. 記号 $c_{e-p / \psi}$ の右下添字 $\Psi$ は,$c_{e-p / \Psi}$ が過小応力型弾・塑性球面波伝ぱ速度の式であることを表す.$c$ と $c_{e-p / \Psi}$ の理論式は同であり，式( 59) となる . ただし前者では $\Phi \neq 0$ であり，後者では $\Phi=0$ である.$c_{e-p}$ は $c$ より小さい .

$$
\begin{aligned}
& c_{e-p}=c_{e-p / \Psi}=(c)_{\eta=\infty}=(c)_{\Phi=0} \\
&=\sqrt{\frac{\frac{1-v}{E}+\frac{\Psi}{3}}{\rho \frac{1-2 v}{E}\left(\frac{1+v}{E}+\Psi\right)}}=c_{3} \sqrt{1+\frac{2\left(\dot{\sigma}_{r r}-\dot{\sigma}_{\varphi \varphi}\right)}{3 K\left(\dot{\varepsilon}_{r r}-\dot{\varepsilon}_{\varphi \varphi}\right)}}=c_{3} \sqrt{1+4 \dot{\bar{\sigma}} /(9 K \dot{L})}=c_{3} \sqrt{1+\frac{4}{9 K} \frac{d \bar{\sigma}}{d L}} \\
& \text { (70a) , (70b) , ( 70c ), (70d) , (70e) , (70f) , (70g) }
\end{aligned}
$$

$$
c_{e-p} \leq c
$$

式(70e) (70f)および (70g) は以下のようにして求めることができる . 式( 69)で $\Phi=0$ と置くと次式を得る

$$
\dot{\varepsilon}_{r r}-\dot{\varepsilon}_{\varphi \varphi}=\left(\frac{1}{2 \mu}+\Psi\right)\left(\dot{\sigma}_{r r}-\dot{\sigma}_{\varphi \varphi}\right) \text { when } \bar{\sigma}>\sigma_{Y}
$$

式(72)から， $\Psi$ は $\Psi 0$ であるので，次式が成立する .

$$
\left(\dot{\varepsilon}_{r r}-\dot{\varepsilon}_{\varphi \varphi}\right)\left(\dot{\sigma}_{r r}-\dot{\sigma}_{\varphi \varphi}\right)>0
$$

従って，式(70e) は，式(70d)と(72)から，求めることができる.式(70f)は，式(73)を考慮して，式(47)，(49) および (70e) から求めることができる . 過小応力型弾・塑性球面波伝ば理論に関する式は , 弾・塑・粘塑性球面波 伝ば理論において, 過大応力関数 $\Phi$ を零と置くこと, および, 弾性と非弾性変形の判別のパラメータ, 過大応力 $F$ を相当応力 $\bar{\sigma}$ に置換することによって求めることができる. 過小応力型弾・塑性球面波伝ぱ速度 $c_{e-p / \Psi}$, 式 $(70 \mathrm{e})$ と(70f) は形式的に速度系であるが, 内容は, 式 $(70 \mathrm{~g})$ からひずみ速度および応力速度不依存性であることがわか る.式(70e) は, 式( 65c) で $\Phi=0$ と置くことによっても求めることができる.式(70f) は, 式(73)を考慮すると，

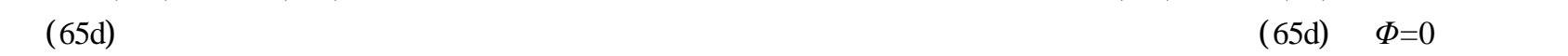
とによっても求めることもできる.

\section{$3 \cdot 5 c_{e-p / \Psi}$ と $c_{e-p / U}$ の関係}

記号 $c_{e-p / U}$ の右下添字 $U$ は, $c_{e-p / U}$ カ塑性ポテンシャル型弾・塑性球面波伝は速度の式であることを表す.$U$ は弾・塑性 体の相当応力・相当塑性ひずみ関係式の勾配 , $U=d \bar{\sigma} / d \bar{\varepsilon} \bar{\varepsilon}^{p}$ である. $c_{e-p}$ は形式上 2 種類,$c_{e-p / \Psi}$ と $c_{e-p / U}$ か存在する.$c_{e-p / \Psi}$ は第 3.4 節て言述されている. 塑性ポテンシャル型弾・塑性球面波伝は理侖は, 文献 (6)に記述されているが, 弚れを別の 方法て導出することかできる. 乥れは, 過小応力型弾・塑性球面波伝は理侖（第 3.4 節）において， $\Psi$ を $\Psi=3 /(2 U$ )に置 換することによって求めることかできる. $c_{e-p / \Psi}$ と $c_{e-p / U}$ は等しい.

$$
c_{e-p}=c_{e-p / \Psi}=c_{e-p / U}
$$




\section{$3 \cdot 6$ 弾・粘塑性体の場合}

弾・粘塑性体に対する理論弾・粘塑性球面波伝ぱ速度 $c_{e-v p}$ は, 弾・塑・粘塑性球面波伝ば理論において $\Psi=0$ および $\Phi \neq 0$ の場合であるので, 式( 59)で $\Psi=0$ と置くと，平面弾性波伝ば速度 , 式( 60a,b) と同じになる .

$$
c_{e-v p}=c_{1}
$$

ここで, $c_{e-v p}$ の右下添字 $e-v p$ は弾・粘塑性を表す . 理論弾・粘塑性球面波伝ば速度は, ひずみ, 応力 ,ひずみ速 度および応力速度に無関係であり，しかも，平面弾性波伝ば速度と一致する．

\section{4. 計 算 例}

厚肉球に生じる各物理量は, $r-t$ 平面上で格子を作り ${ }^{(6)}$, 特性曲線に沿って成立する常微分方程式 $(64 \mathrm{a}, \mathrm{b}, \mathrm{c})$ を 数值積分することによって求めることができる. 特性曲線 $d r / d t= \pm c$ は曲線であるが , $r-t$ 平面上での微小格子 $\triangle t-$ $\triangle r$ 間では直線近似することができる . 計算手順は文献(6) と同樣である . 厚肉球の寸法は内径 $d_{i}=2 r_{i}=50[\mathrm{~mm}]$, 外 径 $d_{o}=2 r_{o}=250[\mathrm{~mm}]$ とした . 衝撃負荷条件は空洞面に対する点対称粒子速度負荷条件， $v_{r}=v_{r}\left(r_{i}, t\right)=v_{i}(t)$ とした . 半 径方向メッシュは $\triangle r=0.2[\mathrm{~mm}]$ とし , 時間メッシュは $\triangle t=\Delta r / c_{1}=0.0527[\mu \mathrm{s}]$ であり , $c_{1}=3.80[\mathrm{~km} / \mathrm{s}]$ である . 空洞の 全面で半径方向粒子速 $v_{r}$ が放物形て増加し，一定の立ち上がり時間 $t_{r}=5[\mu \mathrm{s}]$ 後一定値 $v_{0}=25[\mathrm{~m} / \mathrm{s}]$ になるとした ${ }^{(6)}$. 計算に用いた材料定数を表 1 に示す. 静的単純引張り応力・ひずみ曲線の定数 $a, b, a_{1}$ および $b_{1}$ は黄銅の值 ${ }^{(10)}$ を用いた . しかし, 弚の動的単純引張り応力・ひずみ曲線が不明であるので, 弚のひずみ速度依存性の程度を適 当に仮定して光の定数 $\zeta, \eta, k_{1}$ および $k_{2}$ を決定した .仮定した材料定数を用いた ,一次元棒の単純引張り弾・塑・ 粘塑性応力・ひずみ関係は , 式(3a)から

$$
\dot{\varepsilon}=\left\{\frac{1}{E}+\frac{2}{3 \zeta}\left(E\left|\frac{\varepsilon}{\sigma}\right|-1\right)^{k_{1}}\right\} \dot{\sigma}+\frac{2}{3 \eta}\left(\left|\frac{\sigma}{\sigma_{S}}\right|-1\right)^{k_{2}} \sigma \text { when }|\sigma|>\left|\sigma_{S}\right|
$$

である(11). 式(76)を用いた計算結果を破線で図 2 に示す . 仮定したひずみ速度依存性の程度が判る .

差分計算谷のものの計算精度は入力エネルギ $E_{i n}$ と出力エネルギ $E_{o u}$ の相対誤差 $E_{e r}$ て評価した . $E_{\text {ou }}$ は運動エネ ルギ $E_{k i}$ と変形ひずみエネルギ $E_{d e}$ の和である ${ }^{(6)}$.

図 3 に $r$ - $t$ 平面上での計算範囲の位置と時間を示す 半径方向での先行波 $c_{1}$ の往復時間は, $2\left(r_{o}-r_{i}\right) / c_{1}=52.7[\mu$ s]である，厚肉球外面での境界条件は自由面とし，計算時間は，先行波の外面からの反射波か椡達する時間まで とした .

図 4〜12 は光れ光れ対応する，各図において，弾・塑・粘塑性構成式を用いた結果を実線（以下，E-P-VP理論

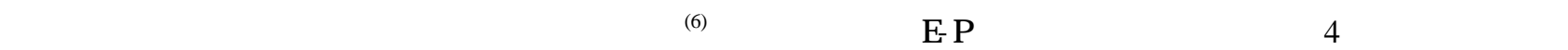
速度 $v_{r}$ の分布を示す, $v_{i}(t)$ は厚肉球内面 $\left(r=r_{1}=r_{i}\right)$ における，半径方向粒子速度負荷条件による衝撃面粒子速度 である. $v_{r}$ は両理論とも衝撃面からの距離の増加と共に著しく減少する $\cdot v_{r}$ は初期降伏点直後, E- P-VP理論が E-P 理論より大きくなるが, 产の後, E-P-VP理論がE-P理論より小さ目になり, 両理論の差は時間の経過と共に減少 する .

図 5 と 6 に相当応力の分布を示す. 両理論による先行波の伝ぱ速度は $c_{1}$ である. $\bar{\sigma}$ の伝ぱの樣子が良く判る. E-P-VP理論の $\bar{\sigma}$ は，ひずみ速度依存性のため，E-P理論の光れより大きくなる . 図 6 から， $\bar{\sigma}$ は両理論とも $r$ の 増加と共に著しく減少する。

図 7 は弧ひずみの分布を示す.$L$ は両理論とも, $r$ の増加と共に著しく減少する.両理論による $L$ の差は殆ど ない. 対数弧ひずみ速度の最大值は, 両理論共 , $(\log L)_{\max }=3.5[1 / \mathrm{s}]$ である.

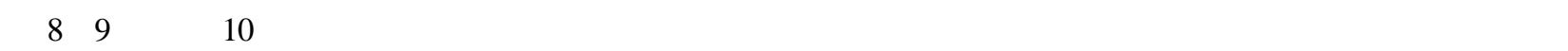
ずみ関係を示す． 
Table 1 Values of material constants

\begin{tabular}{|l|}
\hline$E=98.2\left[\mathrm{GPa}, \quad \sigma_{\mathrm{Y}}=126[\mathrm{MPa}]\right.$ \\
\hline$\mu=38.8\left[\mathrm{GPa}, \mathrm{\tau}_{\mathrm{Y}}=72.7[\mathrm{MPa}]\right.$ \\
\hline $\mathrm{a}=0.0287, \quad \mathrm{~b}=2.32$ \\
\hline $\mathrm{a}_{\mathrm{S}}=0.0948, \quad \mathrm{~b}_{\mathrm{s}}=2.16$ \\
\hline$\rho=8.39 \times 10^{-6}\left[\mathrm{~kg} / \mathrm{mm}^{3}\right]$ \\
\hline$\zeta=11.8[\mathrm{GPa}], \quad \eta=0.118[\mathrm{MPa} \cdot \mathrm{s}]$ \\
\hline $\mathrm{k}_{1}=0.85, \quad \mathrm{k}_{2}=5.0$ \\
\hline
\end{tabular}

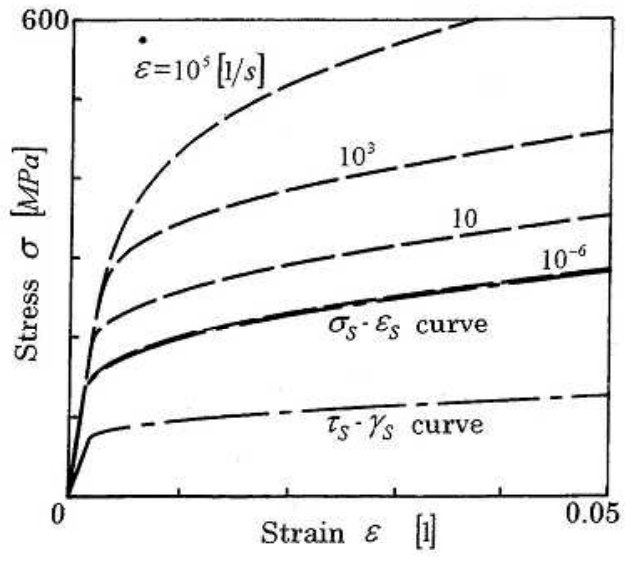

Fig.2 Dynamic stress-strain curves in tension.

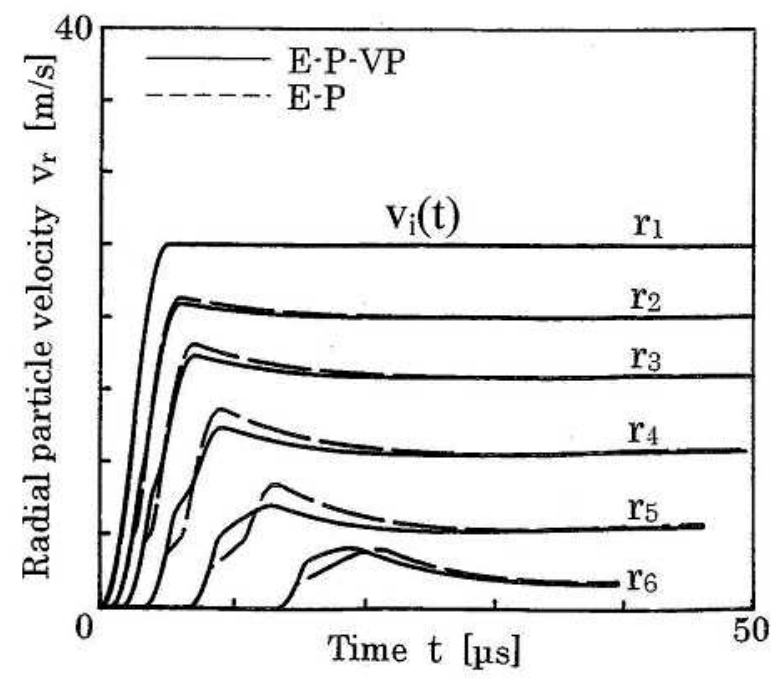

Fig.4 Radial particle velocity in $\left(t, v_{r}\right)$ plane.

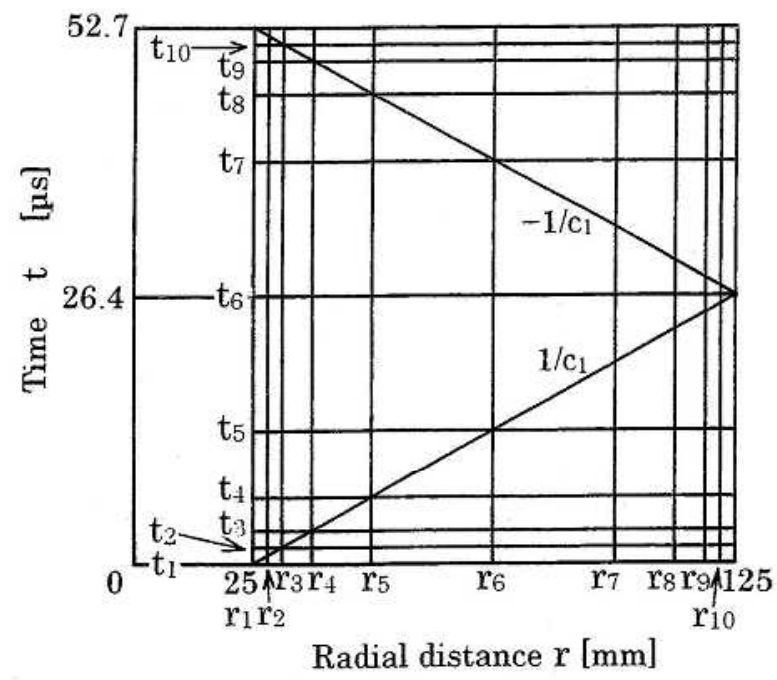

Fig.3 Distances and times used in calculation in $(r, t)$ plane. $r_{1}=r_{i}=25.0, r_{2}=28.1, r_{3}=31.3, r_{4}=37.5$, $r_{5}=50.0, \quad r_{6}=75.0, \quad r_{7}=100.0, r_{8}=112.5, r_{9}=118.8, r_{10}=$ 121.9 and $r_{0}=125[\mathrm{~mm}] . \quad \mathrm{t}_{1}=0.0, \quad \mathrm{t}_{2}=1.65, \mathrm{t}_{3}=3.29, \mathrm{t}_{4}=$ $6.58, \mathrm{t}_{5}=13.2, \mathrm{t}_{6}=26.3, \mathrm{t}_{7}=39.5, \mathrm{t}_{8}=46.1, \mathrm{t}_{9}=49.4$ and $\mathrm{t}_{10}=51.0[\mu \mathrm{s}]$.

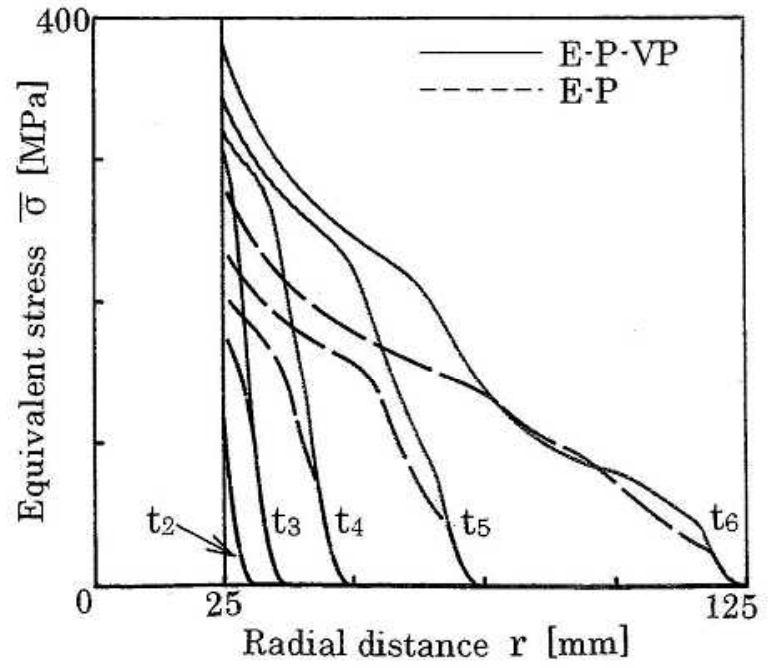

Fig. 5 Equivalent stress in $(r, \bar{\sigma})$ plane.

図 8 から ,一定の $\varepsilon_{r r}$ に対応する $\sigma_{r r}$ は両理論とも $r$ の増加と共に著しく減少する .E-P-VP理論の $\sigma_{r r}$ は E-P理論 の弚れより大きくなる. 各位置での $\sigma_{r r}$ は $\varepsilon_{r r}$ が大きくなるにつれて両理論とも，弚れ光れ，差が小さくなる

図 9 から，一定の $\varepsilon_{\varphi \varphi}$ に対応する $\sigma_{\varphi \varphi}$ は，両理論とも，rの増加と共に著しく減少する. E-P-VP理論の $\sigma_{\varphi \varphi}$ は立 ち上がり時間 (図 4) 直後まででは E-P 理論の弚れより小さくなるが, 弚の後では大きくなる. 各位置での $\sigma_{\varphi \varphi}$ は， $\varepsilon_{\varphi \varphi}$ が大きくなるにつれて，両理論とも，乥れ光れ，殆ど一本の線に乗る． 


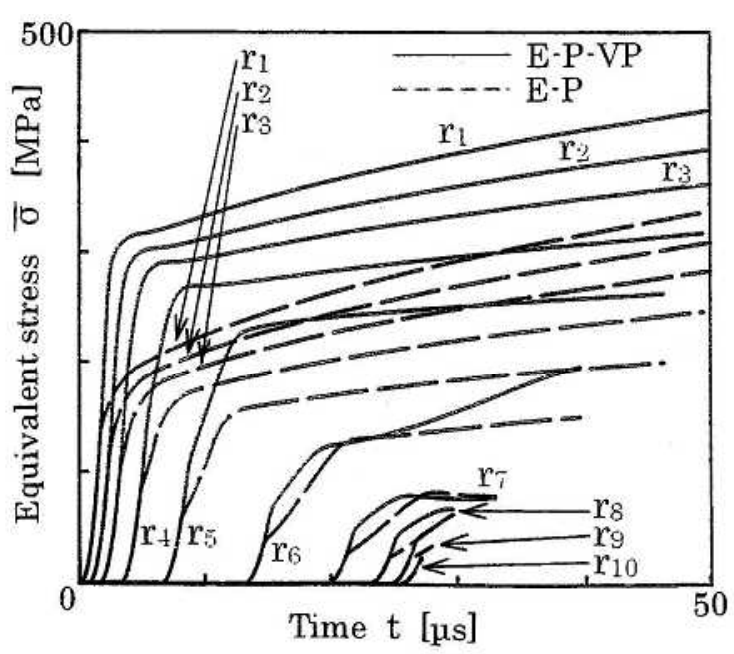

Fig. 6 Equivalent stress in $(t, \bar{\sigma})$ plane.

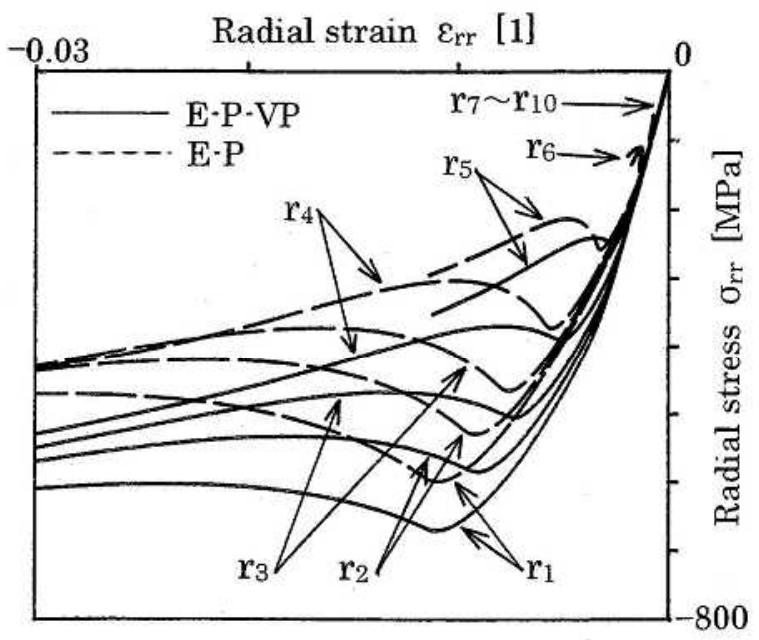

Fig. 8 Relations between radial stress and strain.

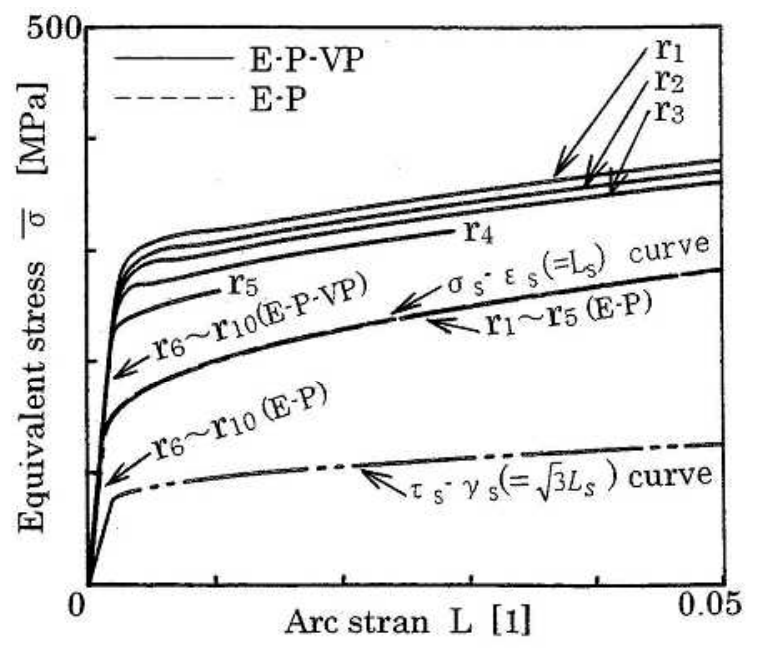

Fig.10 Relations between equivalent stress and arc strain.

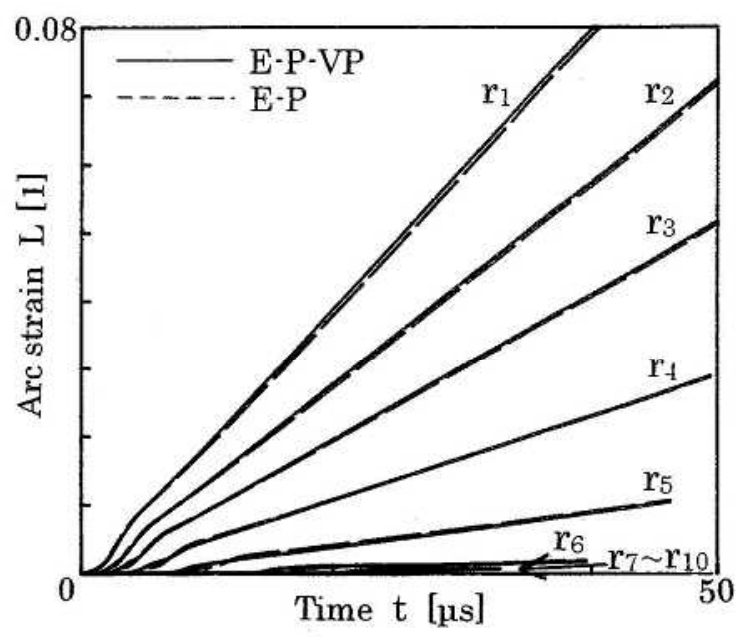

Fig. 7 Arc strain in (t, L) plane.

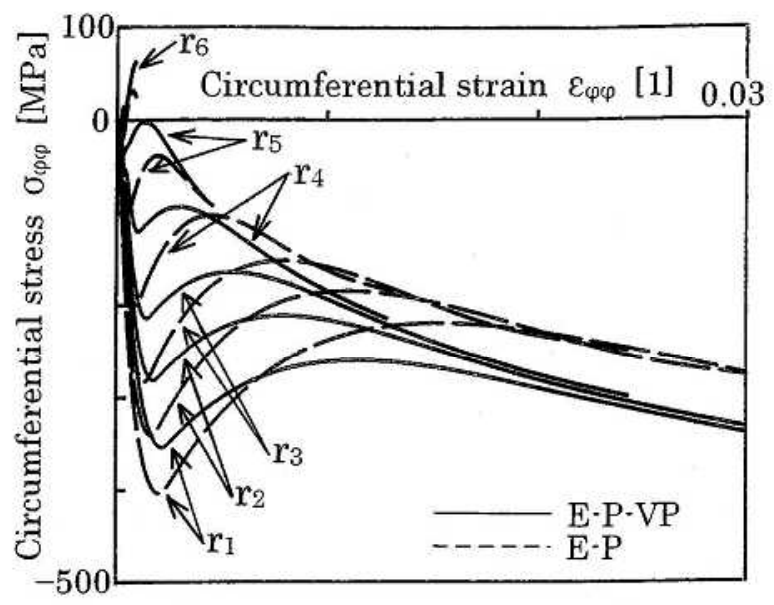

Fig.9 Relations between circumferential stress and strain.

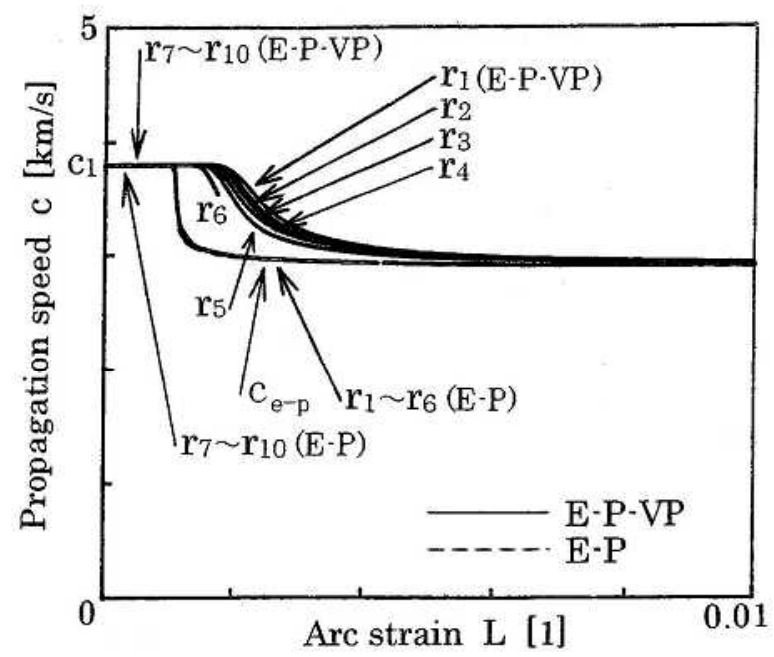

Fig.11 Relations between propagation speed and arc strain. 


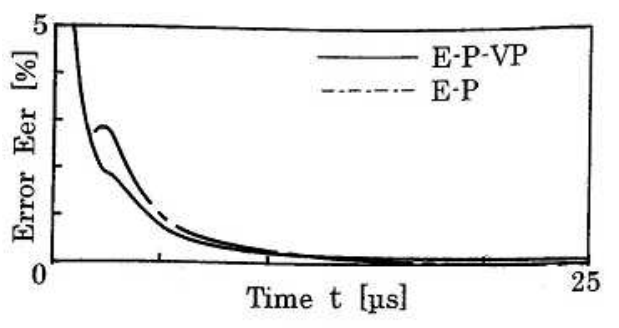

Fig.12 Error.

図 10 から，一定の $L$ に対応する，E-P理論による $\bar{\sigma}$ は,増加する $r$ に無関係に一定曲線 (静的単純引張り曲線) と一致する.すなわち，E-P理論による

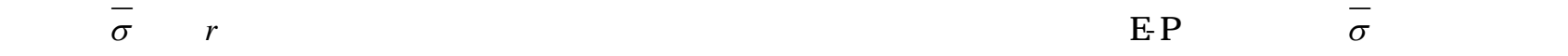
なわち,E-P-VP理論による $\bar{\sigma}$ はひずみ速度依存性を示している.成分の $\sigma_{r r}-\varepsilon_{r r}$ 関係 (図 8) と $\sigma_{\varphi \varphi}-\varepsilon_{\varphi \varphi}$ 関係 (図 9) は幾分複雑であるが，これらを一つにまとめた $\bar{\sigma}-L$ 関係は極めて単純になっている .

図 11 に伝ば速度・弧ひずみ関係を示す，一定の $L$ に対応する，E-P理論による球面波伝ば速度 $c_{e-p}$ は，増加す る $r$ に無関係に一本の曲線に乗る.すなわち,$c_{e-p}$ は,ひずみ速度不依存性を示している.一定の $L$ に対応する， E-P-VP理論による球面波伝ぱ速度 $c$ は $r$ の増加と共に, 従って, 弧ひずみ速度の減少に対応して減衰し, $c_{e-p}$ に

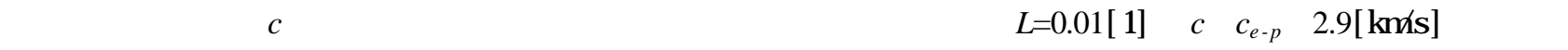
肉厚のほぼ半分まででは $\left(r=r_{1} \sim r_{6}\right), c$ と $c_{e-p}$ は，光れ㢳れ，球面弾・塑・粘塑性波と弾・塑性波として伝ぱし， 兴の後 $\left(r=r_{7} \sim r_{10}\right)$, 両波は共に球面弾性波として伝ぱする. $c$ と $c_{e-p}$ の大小関係は数值解析的にも式 $(71)$ を満足 する .

図 12 に両計算における相対誤差の分布を示す . 両理論の相対誤差は立ち上がり時間までを除くと $1[\%$ \%下で あるので, 差分計算帝のものは信頼し得る .

\section{5. 結 論}

本論文では, 厚肉球体の非弾性球面波伝ぱの理論解析およひ数值計算を行った．まず, 非圧縮性一般弾・塑・ 粘塑性構成式から球体の弾・塑・粘塑性構成式を導出した . 次に, 運動方程式, 連続の式および弾・塑・粘塑性 構成式を用いて理論球面弾・塑・粘塑性波伝ば速度の式を導出し, 乥して, 特性曲線上で成立する, 粒子速度, 応力およびひずみ間の常微分方程式を導出した .さらに, 導出した理論球面弾・塑・粘塑性波伝ぱ速度の式が ずみ速度および応力速度依存性であることを解析的に示した．導出した理論球面弾・塑・粘塑性波伝ぱ速度の式 から, 過小応力型球面弾・塑性波伝ぱ速度の式を導出し, 光して, この式が, 既存の, 塑性ポテンシャル型球面 弾・塑性波伝ぱ速度の式と同じになることを示した . また，球面弾・塑・粘塑性波伝は理論か球面弾・塑性波伝 ぱ理論を含むことを理論的に示した 。

厚肉球体の内面に点対称の半径方向粒子速度を負荷した場合の球面弾・塑・粘塑性波伝ぱの数値計算を，差分 法で行った . 炎の結果, 半径方向粒子速度 , 半径方向と周方向応力, 相当応力, 半径方向と周方向ひずみおよび 弧ひずみなどは, 半径方向距離の増加と共に, 著しく減衰する.弾・塑・粘塑性応力波伝ぱ理論における相当 応力は, 相当応力・弧ひずみ平面上で, 半径方向距離の増加と共に減衰し (応力のひずみ速度依存性), 弚し て, 弾・塑性応力波伝ぱ理論における相当応力に近づく. 球面弾・塑・粘塑性応力波伝ぱ速度は, 球面弾・ 塑・粘塑性応力波伝ぱ速度・弧ひずみ平面上で , 半径方向距離の増加と共に減少し（伝ぱ速度のひずみ速度 (依存性), 弚して, 球面弾・塑性応力波伝ぱ速度に近づく。

\section{参 考 文 献}

(1) Hunter, S. C., "The Propagation of SphericallySymmetric Disturbance in Ideally Plastic Materials", Proceedings of Conference on Properties of Materials at High Rate of Strains, (The Institution of Mechanical Engineers, London, 1957), pp.147-155. 
(2) Hopkins, H. G, "Dynamic Expansion of Spherical Cavities in Metals", in Progress in Solid Mechanics (edited by Sneddon, I. N. and Hill, R.) Vol., Ch. Ill . (North-Holland, Amsterdam, 1960), pp.83-163.

(3) Cristescu, N., "European Contributions to Dynamic Loading and Plastic Waves", Proceedings of the Second Symposium on Naval Structural Mechanics (edited by Lee, E. H. and Symonds, P. S.) (Pergamon Press, Oxford, 1960), pp.385-442.

(4) Srinivasan, M. and Ting, T. C. T., "Initiation of Spherical Elastic-Plastic Boundaries due to Loading at a Spherical Cavity", $J$. Mech. Phys. Solids, 22 (1974), pp.415-435.

(5) Fotiu, P. A. and Ziegler, F., “The propagation of Spherical Waves in Rate-Sensitive Elastic-Plastic Materials", Int. J. Solids Structs., 33-6 (1996), pp.811-833.

(6) 谷本 昇, “厚肉球の弾・塑性球面波伝ぱの解析”, 日本機械学会論文集, 77 巻 775 号, A 編(2011), pp.505-516.

(7) 谷本 昇, “弾・塑・粘塑性構成式の一形式”, 日本機械学会論文集, 67 巻 655 号, A 編(2001), pp.519-526.

(8) セドフ, L. I., 連続体力学, 1 巻 (大橋義夫 訳, 1979), p.117-130, 森北出版.

（9）ファン, Y. C., 固体の力学/理論 (大橋義夫, 村上澄男, 神谷紀生 訳, 1970), p.109-111, 倍風館.

(10) 大橋義夫, 徳田正孝, 田中義克, 伊藤昇平, “組合せ負荷を受ける黄銅の塑性変形に対する精密な実験的研究”, 日本機械学会論文集 (第 1 部)，43 巻 374 号 (1977)，pp.3732-3743.

(11) Tanimoto, N., "One-Dimensional Theory of Elastic-Plastic-Viscoplastic Stress Waves of Solid in Uniaxial Stress State", Theoret. and Appl. Mechs., Jpn., 47 (1998), pp.67-77 